\title{
The Influence the Level of Regional Wealth, Capital Expenditure, Intergovernmental Revenue and BPK Audit Findings On Local Government Performance with Government Size as Moderating Variable (Study at Regency / City Government in Jambi Province)
}

\author{
Rico Wijaya ${ }^{1}$, Agus Solikhin ${ }^{2}$ \\ ${ }^{12}$ Faculty of Economics and Business, Jambi University, Indonesia \\ \{ricowijaya1981@yahoo.com\}
}

\begin{abstract}
The purpose of this study is to examine and analyze the effect of the level of regional wealth on local government performance, to examine and to analyze the effect of capital expenditure on local government performance, to examine and to analyze the effect of intergovernmental revenue on local government performance, to examine and to analyze the effect of BPK audit findings on local government performance. Then also to examine government size moderating the relationship between the level of regional wealth, capital expenditures, intergovernmental revenue and BPK audit findings on the performance of local governments. This research was conducted in eleven (11) districts / cities throughout Jambi Province. The research method used is quantitative research and the analytical tool used in this study is to use the Smart PLS version 5.0 application. The results of this study are that level of regional wealth has a significant positive effect on local government performance, capital expenditure has a significant positive effect on local government performance, Intergovernmental revenue has no significant positive effect on local government performance, BPK audit findings have no significant positive effect on local government performance and Government size is only able to moderate the relationship between the level of regional wealth and the performance of local governments.
\end{abstract}

Keywords: Level of Regional Wealth; Capital Expenditure; Intergovernmental Revenue; BPK Audit Findings; Government Size; Local Government Performance

\section{Introduction}

Audit opinion of the Supreme Audit Agency of the Republic of Indonesia (BPK RI) is a statement or written evidence whether a financial report has been fairly presented in various material aspects based on an evaluation of the audit evidence obtained and the audit findings. The BPK audit opinion is one of the benchmarks for the success of accountability in regional financial management. Local governments are led to continue to show that accountability and transparency in regional financial management into good governance and clean governance are achieved. According to Retnowati (2016), local government is the party or part that carries out activities of all aspects of the wheels of the government in order to create a clean government [1]. 
There are four kinds of audit opinion issued or issued by the Supreme Audit Agency, namely 1) unqualified opinion (WTP), 2) unqualified opinion (WDP), 3) unreasonable (TW), and 4) does not provide income (TMP). Indonesia began to enact decentralization and entered the era of regional autonomy after the issuance of Law Number 22 of 1999 concerning regional autonomy, as amended by Law Number 32 of 2004 concerning regional government and subsequently amended again by Law No. 23 of 2014, concerning Regional Government and concerning Financial Balance between Regional Governments having the authority to regulate and manage government affairs themselves based on autonomy. The realization of the regional autonomy system basically began in 1999, where in general the regional government was given freedom in managing the existing regional potential. Creating people's welfare is the main goal of the regional autonomy system [2]. Although sometimes regional autonomy still has problems in its implementation.

In the regional financial governance system in Indonesia, it is specifically regulated in a standard in Indonesia known as the Government Accounting Standards (SAP). Every preparation of financial reports is required to use SAP, this is intended to be effective, efficient, and accountable. To assess government performance, especially financial performance evaluation, it is necessary to carry out continuous evaluation in order to assess whether it is in accordance with the applicable SAP [2]. Based on the opinion of the representative LKPD BPK Jambi Province 2016-2018 can be seen as shown in the table below:

Table 1. Opinion LKPD BPK Representative of Jambi Province 2016-2018

\begin{tabular}{|l|l|r|r|r|}
\hline \multirow{2}{*}{ No } & \multicolumn{2}{|c|}{ Daerah } & \multicolumn{3}{c|}{ Opini } \\
\cline { 3 - 5 } & & $\mathbf{2 0 1 6}$ & $\mathbf{2 0 1 7}$ & $\mathbf{2 0 1 8}$ \\
\hline 1 & Provinsi Jambi & WTP & WTP & WTP \\
\hline 2 & Sungai Penuh & WTP & WTP & WTP \\
\hline 3 & Kerinci & WTP & WTP & WTP \\
\hline 4 & Bungo & WDP & WDP & WTP \\
\hline 5 & Tebo & WTP & WTP & WTP \\
\hline 6 & Batanghari & WTP & WTP & WTP \\
\hline 7 & Kota Jambi & WTP & WTP & WTP \\
\hline 8 & Sarolangun & WTP & WTP & WTP \\
\hline 9 & Merangin & WTP & WTP & WTP \\
\hline 10 & Muaro Jambi & TMP & WDP & WTP \\
\hline 11 & Tanjung Jabung Barat & WDP & WTP & WTP \\
\hline 12 & Tanjung Jabung Timur & &
\end{tabular}

It can be seen from the table above that those who got the WTP opinion issued by the BPK representatives of Jambi Province in a row for 3 years were the local governments of Jambi Province, Sungai Penuh, Kerinci, Tebo, Batanghari, Jambi City, Sarolangun, Meragin and Muaro Jambi. However, on the other hand, district / city governments that have not received WTP for 3 consecutive years are Bungo District, West Tanjung Jabung and East Tanjung Jabung. Government performance can be measured by several factors, including the level of regional wealth. Previous research that examined the effect of the level of regional wealth on government performance was conducted by [3]. The results of his research found that regional wealth had a positive impact on government financial performance. Unlike the results of previous research by Noviyanti and Kiswanto (2016), the results show that the level of regional wealth has no effect on local government performance [4]. This means that large or small regional assets will have an influence on government performance. 
Capital expenditure is a form of instrument used by the government in improving the government's financial performance in terms of adding government fixed assets so that it has benefits in a certain period. Research conducted by Andirfa, et al (2016) shows that capital expenditure activities have a positive effect on the performance stage of local government [5], in contrast to the findings made by Qowi and Prabowo (2017) which found that capital expenditure has a negative effect on local government performance [2]. In general, it can be described that there is still a gap or difference in the results of research on spending on capital expenditure treatment in government.

In general, the General Allocation Fund (DAU) is a fund from the central government or sourced from the APBN aimed at local governments, in order to assist local governments in carrying out their main tasks (tupoksi) for services to the community [6]. Previous research on intergovernmental revenue was conducted by Marhawai (2015). The result was that Intergovernmental revenue had a positive effect on the performance of local governments [7]. In contrast to Andirfa, et al. (2016), the results found that intergovernmental revenue has a negative effect on local government performance [7]. It can be concluded that the size or size of intergovernmental revenue which is assessed as a comparison between the General Allocation Fund (DAU) and total revenue can affect the government's financial performance.

District / City and Provincial governments that have a high number of BPK audit findings, this can prove that the behavior of state administration must have a high commitment in realizing clean governance. In essence, the BPK's findings, whether large or small, the leakage of funds can describe the government's performance, especially the government's financial performance. [2]. Previous research conducted by Renas (2014), Noviyanti and Kiswanto (2016), and Qowi and Prabowo (2017) showed that the BPK audit findings have a negative effect on local government performance. Conceptually and the results of research are very different in that the size of the findings cannot affect the government's financial performance.

The large size of an area can make a strength in the development of the area. Local governments must take assets seriously. The problems that often occur include the lack of maintenance of local government assets so that a lot of regional income is still not maximized, so that asset maintenance funds will appear, so that the allocation of funds for the welfare of the people will decrease (Aminah et al, 2019). The results of research by Renas (2014) which state that government size has a negative effect on local government performance, while Alvini (2018) and Aminah (2019) prove that government size has a positive effect on local government performance. It can be illustrated that large assets or small assets can have an impact on improving the government's financial performance.

Based on the background that has been described, the main problems can be formulated including the following:

a. Does the level of regional wealth have a significant positive effect on local government performance?

b. Does capital expenditure have a significant positive effect on local government performance?

c. Does intergovernmental revenue have a significant positive effect on local government performance?

d. Do BPK's audit findings have a significant positive effect on local government performance?

e. Is the size of the government proven to moderate the relationship between the level of wealth, capital expenditures, intergovernmental revenue and the BPK audit findings on the performance of local governments? 


\section{Methodology}

The type of research designed in this study is quantitative, which tests using deductive theories which are the foundation for taking and solving the problems studied (Indriantoro and Supomo, 2014). The object of this research is the financial statements of district / city governments throughout Jambi Province with as many as 11 regencies and cities throughout Jambi Province.

\subsection{Operational Definition of Variables}

An explanation of each variable used in the study can be seen as below:

Table 2. Operational Definition of Variables

\begin{tabular}{|c|c|c|c|}
\hline No. & Variable & Measure & Size scale \\
\hline 1. & $\begin{array}{l}\text { Regional Financial Performance (Y) } \\
\text { Source : Nugroho dan Prasetyo } \\
\text { (2018) [9]. }\end{array}$ & $\begin{array}{l}\text { Expenditure Realization } \\
\text { Efficiency }=\text { Revenue Realization }\end{array}$ & Ratio \\
\hline 2. & $\begin{array}{l}\text { Regional Wealth Level (X1) } \\
\text { Source : Sudarsana dan Raharjo } \\
(2013)[8]\end{array}$ & $\begin{array}{l}\text { TKD = PAD } \\
\text { Total Income }\end{array}$ & Ratio \\
\hline 3. & $\begin{array}{l}\text { Capital Expenditure }\left(\mathrm{X}_{2}\right) \\
\text { Source : Sudarsana dan Raharjo } \\
(2013)[8]\end{array}$ & $\begin{array}{l}\text { BM = Capital Expenditure } \\
\text { Total Expenditure Reatization }\end{array}$ & Ratio \\
\hline 4. & $\begin{array}{l}\text { Intergovernmental revenue }\left(\mathrm{X}_{3}\right) \\
\text { Source : Sudarsana dan Raharjo } \\
(2013)[8]\end{array}$ & $\begin{array}{l}\mathrm{IR}=\mathrm{DAU} \\
\text { Total Income }\end{array}$ & Ratio \\
\hline 5. & $\begin{array}{l}\text { BPK Audit Findings } \\
\left(\mathrm{X}_{4}\right) \\
\text { Source: Sudarsana dan Raharjo } \\
(2013)[8]\end{array}$ & $\begin{array}{l}\text { Audit findings use dummy variables. The dummy } \\
\text { variable only has } 2 \text { (two) values, namely } 1 \text { and the } \\
\text { value } 0 \text {, and is given the symbol } D \text {. The dummy } \\
\text { has a value of } 1(\mathrm{D}=1) \text { if } \\
\text { The local government has BPK audit findings and } \\
(\mathrm{D}=0) \text { if there are no BPK findings }\end{array}$ & Nominal \\
\hline 6 & $\begin{array}{l}\text { Government Size (M) Source : } \\
\text { Sudarsana dan Raharjo (2013) [8] }\end{array}$ & $\mathrm{SP}=$ Logarithm natural (Ln) Government Assets & Decimal \\
\hline
\end{tabular}

\subsection{Research Model}

The design of this research model can be seen as follows:

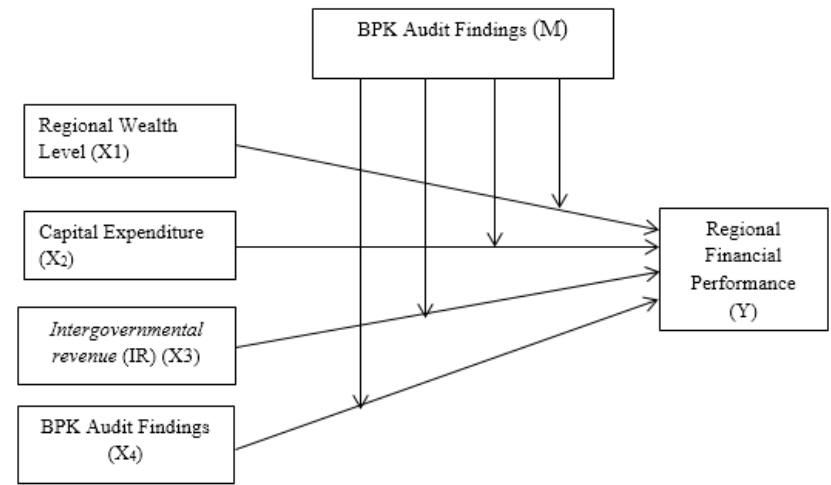

Fig 1. Research Model 
This study has a research design in the form of seeing the performance achievements that have been carried out by local governments in Jambi Province. The object of research is the financial reports issued by each local government, both the Jambi provincial government, and all district / city government financial reports in Jambi Province. The research was conducted for 3 consecutive years $(2016,2017,2018)$. Research activities include identifying financial posts that are related to the variables in this study. It is hoped that this research can make a small contribution to improving the financial performance of local governments in Jambi Province.

\subsection{Analysis Tools.}

This study uses data processing techniques carried out using the WarpPLS version 5 application program, which aims to examine the effect of the independent and dependent variables as well as the mediating variables. In other words, path analysis is an extension of multiple linear regression analysis in which the use of regression analysis aims to estimate the causal relationship between variables (casual models) that have been previously determined based on theory. This study uses a confidence level of $5 \%$ or a degree of 0.05 .

\subsubsection{Hypothesis Evaluation}

The final step in evaluating the structural model that must be done is to look at the significant value of the P-value to determine the effect between variables based on the hypotheses built through the resampling procedure. To see the evaluation of the hypothesis, it can be removed from the results of the WrapPLS application output in the view path coefficients and P-value section. According to Ghozali and Latan (2014), significant values were used with a P-value of 0.10 (significance level $=10 \%), 0.05$ (significance level $=5 \%$ ) and 0.01 (significance level $=1 \%$ ). This study used a P-value of 0.05 (significance level $=5 \%$ [10].

\subsubsection{Moderation Effect Test}

Testing the moderating effect in the WarpPLS 5.0 application can be done directly by using the moderating link option menu, where it can be directly proven whether the research is moderating or not. To see the evaluation of the moderation test, it can be removed from the output results of the WrapPLS application in the view section of the path coefficients and Pvalue, where it can be seen that the multiplication between independent variables and moderating variables. According to Ghozali and Latan, the magnitude of the significant value used in determining moderation occurs on condition that it is positive and the P-value is 0.10 $($ significance level $=10 \%), 0.05($ significance level $=5 \%)$ and $0.01($ significance level $=1 \%)$ adjusted for significance level in each study. This study used a P-value of 0.05 (significance level $=5 \%$ ) $[10]$.

\subsection{Hypothesis}

Based on the background, phenomena and previous research above, this study has several hypotheses as follows:

H1: The level of regional wealth has a positive effect on local government performance

$\mathrm{H} 2$ : Capital spending has a positive effect on local government performance.

H3: Intergovernmental revenue has a positive effect on local government performance.

H4: BPK's audit findings have a positive effect on local governments. 


\section{Result and Discussion}

Based on the results of statistical tools with WarpPLS Version 5, the following results can be seen:

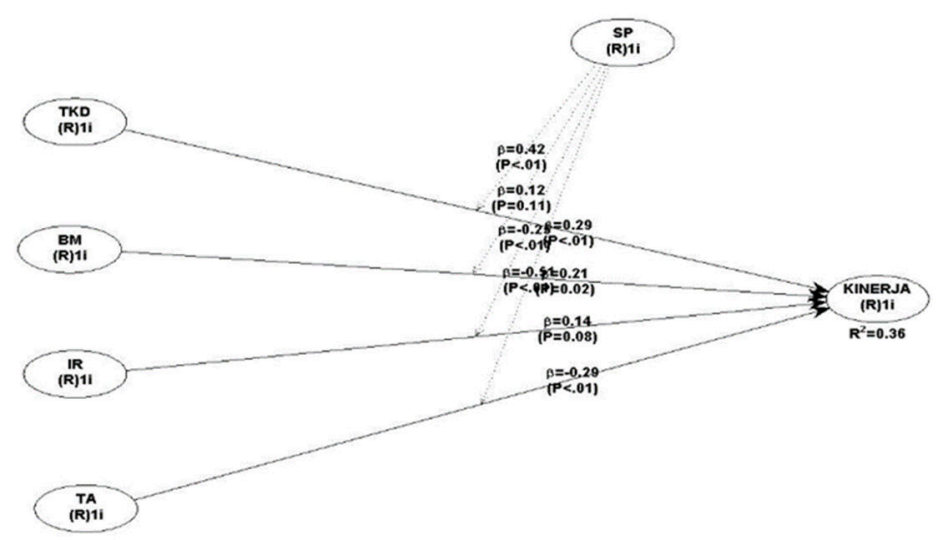

Fig 2. Results of Statistics

Based on the research results, it can be seen that the variables of regional wealth levels and capital expenditures have a significant positive effect on government financial performance. While the intergovernmental revenue variable and audit findings are not proven to have a significant positive effect on government financial performance. To see the overall results it can be seen from the table output Path Coefficients and P Values below:

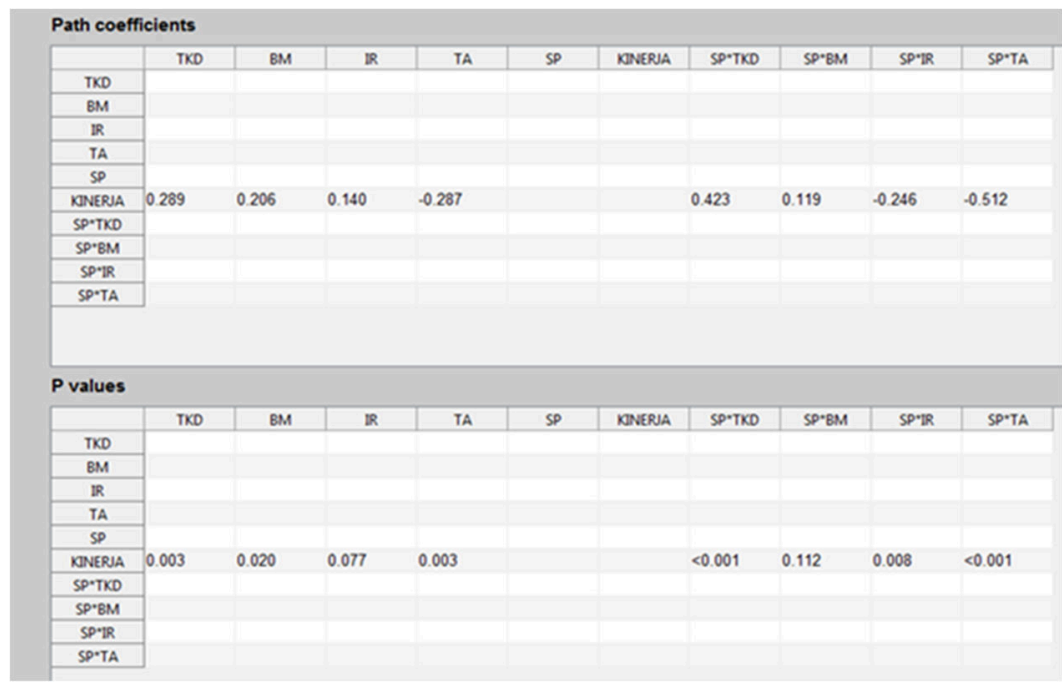

\subsection{Discussion}

Fig 3. Results of Out Put Path Coefficients and P Values

3.1.1 The Influence of Regional Wealth Level and Local Government Performance

Based on the results of the study, the variable level of regional wealth has path coefficients of 0.289 with a significant level of 0.003 and $\leq 0.05$. This means that the level of regional wealth has a significant positive effect, this shows that hypothesis 1 is accepted. The results of this 
study are in line with research conducted by Noviyanti and Kiswanto (2016) [4]. Examining the relationship between the level of regional wealth and the financial performance of local governments, the higher the level of regional wealth, the better the financial performance of local governments and vice versa. The lower the level of regional wealth, the lower the financial performance of the regional government, so that basically the level of regional wealth has no effect on the performance of local governments.

\subsubsection{The Effect of Capital Expenditures on Local Government Performance.}

Referring to the results of research on the relationship between capital expenditures and government finances, it has a coefficient value of 0.206 and a significance value of 0.020 or $\leq$ 0.005 . These results indicate that the relationship between capital expenditure and government finances has a significant positive direction, in other words, hypothesis 2 is accepted. The results of this study are in line with research conducted by Andirfa, et al. (2016) and research by Aminah, et al. (2019), the results found that capital expenditure has a positive impact on local government performance. The policy of increasing the share of capital spending is also an indication that local governments are actually carrying out their duties as agents for the public and legislative interests as their principals (Qowi and Prabowo, 2017).

\subsubsection{The Influence of Intergovernmental Revenue on Local Government Performance}

Based on the results of this research, the Intergovernmental Revenue variable has a positive and insignificant effect on the financial performance of local governments. The output results indicate a coefficient of 0.140 and a significant level of $0.077 \geq 0.05$. This means that hypothesis 3 is rejected. The results of this study are in line with research conducted by Marhawai (2015) and Aminah, et al. (2019) which states that intergovernmental revenue has a positive effect on local government performance, which means that higher intergovernmental revenue also means the better the government's financial performance. The more general allocation funds mean that the greater the funds obtained in financing the main tasks and functions of local governments to improve public services to the community. Increasing the quality of public services will have an impact on better performance. This shows that the local government has succeeded in optimizing these funds (Aminah et al, 2019).

\subsubsection{Effect of BPK Audit Findings on Local Government Performance}

Based on the output results, the coefficient of the BPK audit findings variable coefficient on government financial performance is -0.287 with a significant level of 0.003 . This means that hypothesis 4 is rejected. The existence of audit findings can affect the financial performance of local governments. The results of this study are in line with research conducted by Renas (2014), Noviyanti and Kiswanto (2016), and Qowi and Prabowo (2017) showing the same results that BPK audit findings have a negative effect on local government performance. From an agency point of view, local governments that have a high number of BPK audit findings indicate that opportunistic behavior (moral hazard) is still strong in the administration of its regional government. Supposedly the BPK audit can be used as a mechanism to minimize the risk of moral hazard and other forms of agency problems within the local government. 
3.1.5. Government size moderates the relationship between level of wealth, regional capital expenditures, intergovernmental revenue and BPK audit findings on local government performance

Based on the results of the government's output size in moderating the relationship between the level of wealth, capital spending, intergovernmental revenue and BPK audit findings on local government performance, it is proven that the size of the government can only moderate the relationship between the level of regional wealth and the government's financial performance with a coefficient level of 0.423 with a level of 0.001 below 0.05 . Meanwhile, the other variables were not proven to have moderation. The results of this study prove that a large government size can strengthen the relationship between the level of regional wealth and the financial performance of local governments. With a strong government size and a high level of local wealth can tie the government's financial performance.

\section{Conclusion}

Based on the research results, several conclusions were obtained, including the following:

a. The level of regional wealth has a significant positive effect on local government performance.

b. Capital expenditures have a significant positive effect on local government performance.

c. Intergovernmental revenue has a significant positive effect on local government performance.

d. BPK audit findings have a significant negative effect on local government performance.

e. Government size is only proven to moderate the relationship between the level of wealth and the performance of local governments.

This research should be further developed using other supporting variables and preferably using intervening variables.

\section{References}

[1] Retnowati, Reny. (2016). 'Analisis pengaruh Tingkat Kekayaan Daerah, Ukuran Pemerintah Daerah, Laverage dan Intergovernmental Revenue terhadap Kinerja Keuangan Pemerintah Daerah (Studi Empiris pada Pemerintah Daerah/Kota Se-Jawa Tengah 2011-2013)'. Jurnal Akuntansi Universitas Muhammadiyah Surakarta.

[2] Endri Parwanto, Puji Harto 2017. Pengaruh Hasil Pemeriksaan BPK Terhadap Kinerja Keuangan Pemerintah Daerah. Volume 6, Nomor 1, Halaman 1-9 ISSN (Online): 2337-3806.

[3] Renas, Dul Muid. 2014. "Pengaruh Karakteristik Pemerintah Daerah dan Temuan Audit BPK Terhadap Kinerja Pemerintah Daerah (Studi pada Pemerintah Daerah Kabupaten/ Kota di Provinsi Jawa Tengah Periode 2009-2011”. Diponegoro Journal of Accounting. Vol. 4, No. 3. ISSN: 23373806.

[4] Noviyanti dan Kiswanto 2016. "Pengaruh Karakteristik Pemerintah Daerah, Temuan Audit BPK Terhadap Kinerja Keuangan Pemerintah Daerah". Accounting Analysis Journal Universita Negeri Semarang. Vol. 5, No. 1. ISSN: 2252-6765.

[5] Andirfa, Mulia dan Basri, Hasan dan Majid, M. Shabri.A. 2016. "Pengaruh Belanja Modal, Dana Perimbangan dan Pendapatan Asli Daerah Terhadap Kinerja Keuangan Kabupaten dan Kota di Provinsi Aceh”. Jurnal Magister Akuntansi. Vol. 5, No. 3. ISSN: 2302-0164. 
[6] Aminah, Lim Nur dan Afiah, Nunuy Nur dan Pratama, Arie. 2019. "Pengaruh Size, Wealth, Intergovermental Revenue, dan Belanja Modal Terhadap Kinerja Pemerintah Daerah”. Jurnal SIKAP. Vol. 3, No. 2. ISSN: 2599-1876.

[7] Marhawai. 2015. "Pengaruh Ukuran Legislatif, Kemakmuran Pemerintah Daerah, Ukuran Pemerintah Daerah dan Intergovernmental Revenue terhadap Kinerja Keuangan Pemerintah Daerah (Studi Pada Kabupaten/Kota Di Aceh Tahun 2010 s.d 2014)”. Jurnal Telaah dan Riset Akuntansi. Vol. 8, NO. 1. ISSN: 1693-3397

[8] Sudarsana, H. S., \& Rahardjo, S. N. 2013. Pengaruh Karakteristik Pemerintah Daerah dan Temuan Audit BPK Terhadap Kinerja Pemerintah Daerah (Studi pada Pemerintah Kabupaten/Kota di Indonesia). Diponegoro Journal Of Accounting Volume 2, Nomor 4, Hal 1-13.

[9] Nugroho, T. R., \& Prasetyo, N. E. (2018). Pengaruh Karakteristik Pemerintah Daerah Terhadap Kinerja Keuangan Pemerintah Daerah Kabupaten dan Kota di Jawa Timur (Vol. 7). Madiun: ASSETS Jurnal Akuntansi dan Pendidikan

[10] Ghozali Imam dan Hengky Latan. 2014. Partial Least Squares Konsep, Metode dan Aplikasi Menggunakan Program WarpPLS 5.0. Third Edition. Badan Penerbit Universitas Diponegoro. Semarang 